\title{
Body Dissatisfaction and Perceived Stress Among Obese and Non-Obese University Students in Yogyakarta
}

\author{
Dyah Ayu Kusuma Wardani ${ }^{1}$ and Janatin Hastuti ${ }^{2}$ \\ ${ }^{1}$ Postgraduate Program nutritional Science, Universitas Sebelas Maret, Surakarta, Indonesia \\ ${ }^{2}$ Laboratory of Bioanthropology \& Paleoanthropology, Faculty of Medicine, Universitas Gadjah \\ Mada, Yogyakarta, Indonesia
}

\section{Abstract}

Yogyakarta is one of 16 provinces in Indonesia with the highest obesity prevalence. It is widely known that body dissatisfaction is higher among obese people than those nonobese ones. Young people with obesity may feel distressed and perceived as a condition that causes unhappiness. This study aimed to examine the relationship between body dissatisfaction and observed stress among obese and non-obese university students in

Corresponding Author: Dyah Ayu Kusuma Wardani dyahayukw@student.uns.ac.id

Received: 26 December 2018 Accepted: 23 February 2019 Published: 7 March 2019

Publishing services provided by Knowledge E

(c) Dyah Ayu Kusuma Wardani and Janatin Hastuti. This article is distributed under the terms of the Creative Commons

Attribution License, which permits unrestricted use and redistribution provided that the original author and source are credited.

Selection and Peer-review under the responsibility of the $2 \mathrm{nd}$ International Meeting of Public Health 2016 Conference Committee. Yogyakarta Province. This study is a cross-sectional design in 276 subjects (138 boys and 138 girls) aged 19-25 years at Universitas Gadjah Mada and Universitas Teknologi Yogyakarta. Perceived stress was measured using the ten items Perceived Stress Scale (PSS-10), body dissatisfaction was defined using the Contour Drawing Rating Scale (CDRS), and obesity was defined using body mass index (BMI). BMI $\geq 25 \mathrm{~kg} / \mathrm{m}^{2}$ was considered as obese. The Chi-square and Fisher's exact analyses were performed. The results showed that the prevalence of body dissatisfaction was very high $(90.6 \%$ boys; $88.4 \%$ girls).

Similarly, distribution of perceived stress among university students was high $\mathbf{7 1 . 7 \%}$ boys; $66.7 \%$ girls). Prevalence of body dissatisfaction was higher among obese ones. On the other hand, perceived stress was higher among non-obese students than those fat ones. However, a significant relationship was found only among girls $\left(\chi^{2}: 5.385 ; p\right.$ : 0.020). This study highlighted the high number of body dissatisfaction and perceived stress among university students in Yogyakarta Province. Further studies required for additional understanding factors associated with body dissatisfaction, perceived pressure, and obesity.

Keywords: Body dissatisfaction; perceived stress; body mass index; obesity; university students

\section{Introduction}

Obesity is one of the severe problems faced by the Indonesian government. Yogyakarta is one of 16 provinces in Indonesia with the highest prevalence of obesity (Riskesdas 2013). Obesity prevalence increases every year, reaching $19.7 \%$ in 2013 , higher than in 
2007 (13.9\%) and 2010 (7.8\%)(Riskesdas 2013). Obesity has various impacts on quality of life, social experiences and morbidity (Barasi 2009). Commonly, obesity is related to non-communicable diseases, such as non-insulin dependent diabetes mellitus (diabetes mellitus type 2), cardiovascular disease, cancer and multiple psychological problems (Soegih \& Wiramihardja 2009).

In addition to physical complications, there are also social and major emotional complications following obesity. Obese people often feel anxious, depressed and withdraw from society because of their weight problem (Lahey 1980). Women who are overweight or obese tend to have higher body dissatisfaction than normal ones. They seem to have lower self-esteem and increase depression symptoms (Buxton 2008). A high percentage of average or underweight women was dissatisfied with their body. Body dissatisfaction is reported lower in man, but almost equally as in women, which is $41 \%$ in men and $53 \%$ in women (Norton \& Olds 1996).

It is widely known that body dissatisfaction is higher among obese people than those non-obese ones. Young people with obesity may feel distressed and perceived as a condition that causes unhappiness (Smith et al. 2013). There are positive associations between body weight and stress, but negative associations between stress and weight control behaviors (e.g., diet, weight control and exercise) (Edmond 2006). Richardson et al. (2015) found that nondietary behaviors or physiologic mechanisms associated with high levels of perceived stress that also contributed to severe obesity. Stressed women are more likely to have emotional and uncontrolled eating behaviors. The possible scenario was that perceived importance increased susceptibility of cortisol reactivity to negative moods and self-medication, increased disinhibition and food craving.

The highest attention to the body occurs during adolescence and age of 20s, then decrease with age (Norton \& Olds 1996). The purpose of this paper was to examine the relationship between body dissatisfaction and perceived stress among obese and nonobese university students in Yogyakarta Province. This study was essential to understand how obesity impact body image and perceived stress among university students. We hypothesized that greater body dissatisfaction and perceived stress occurred among obese students than those of normal ones.

\section{Methods}

\subsection{Study population}

This study was a cross-sectional design. Participants were recruited from Universitas Gadjah Mada and Universitas Teknologi Yogyakarta, using quota sampling method. 
A total of 276 subjects was 138 boys and 138 girls, aged $19-25$ years. The data were collected by using anthropometric measurement and questionnaire. The questionnaire was self-administered answered by the participants. A pilot study was performed to test the survey - informed consent was obtained from all participants. This project had been reviewed and approved by the Medical and Health Research Ethics Committee (MHREC) Faculty of Medicine Universitas Gadjah Mada.

\subsection{Anthropometry}

Weight and height were measured to obtain body mass index (BMI). We defined that $\mathrm{BMl} \geq 25 \mathrm{~kg} / \mathrm{m}^{2}$ considered as obese and $\mathrm{BMl}<25 \mathrm{~kg} / \mathrm{m}^{2}$ was non-obese. This category followed BMI classification for the Basic Health Research in Indonesia (Riskesdas, 2013).

\subsection{Assessments and questionnaires}

\subsubsection{Body dissatisfaction assessment}

Body dissatisfaction was evaluated using the Contour Drawing Rating Scale (CDRS), consisting of nine male and nine female contour drawings. The drawing was designed with detailed features, precisely graduated sizes, easily split at the waist for accurate upper and lower body comparison (Thompson \& Gray, 1995). The participant should determine an individual's perceived current and ideal body sizes. Then, the discrepancy between the two measures indicated the level of body dissatisfaction.

\subsubsection{Perceived stress questionnaires}

The instrument used to evaluate perceived stress was the ten items Perceived Stress Scale (PSS) which was known as a reliable and valid measure of the degree which situation in one's life appraised as stressful. It was a brief and easy-to-administer tool for examining issues about the role of appraisal stress level in the etiology of disease and behavioral disorders (Cohen et al., 1983). The questions were about individuals' thoughts and feeling during a month. In each question, participants were asked how often they felt a certain way, from "never" to "very often" then scored $0-4$. Some questions were reversed scoring with the highest score for "never." The PSS-score of $>16$ considered as perceived stress, and PSS-score of $\leq 16$ identified as unperceived stress. This cut-off was according to an average score of a sample for seeking help, i.e., 16; it was assumed that they had a higher level of stress (Cohen \& Williamson, 1988). The Cronbach-alpha 
internal reliability coefficients were 0.716 in pre-test and 0.842 in post-test, with the correlation coefficient was 0.665 for both.

\subsection{Statistical analysis}

Univariate analysis was tested to find the distribution of data, percentage, mean and standard deviation. Hypothesize testing was done using chi-square or Fisher's exact test with a confidence interval of $95 \%$. All statistical analyses were performed using SPSS, version 16 (SPSS 2007).

\section{Results}

The results showed that prevalence of body dissatisfaction was very high $(90.6 \%$ boys; $88.4 \%$ girls), including desired to weight-gain (47.1\% boys; $26.1 \%$ girls) and wished to weight-loss (43.5\% boys; $62.3 \%$ girls). Similarly, distribution of perceived stress among university students was high (71.7\% boys; $66.7 \%$ girls). Prevalence of obesity among boys (16.7\%) was higher than girls (10.9\%).

There was no significant association between body dissatisfaction among obese and non-obese boys and girls ( $p>0.05)$. Prevalence of body dissatisfaction was higher among obese ones ( $95.7 \%$ boys; $100 \%$ girls). It showed that none of the overweight girls dissatisfied by their body. On the other hand, perceived stress was higher among nonobese students ( $72.2 \%$ boys; $69.9 \%$ girls) than those fat ones $(69.6 \%$ boys; $40 \%$ girls). However, a significant relationship was found only among girls $\left(\chi^{2}: 5.385 ; p=0.020\right)$.

\section{Discussion}

Table 1 showed distribution data of age, obesity, body dissatisfaction and perceived stress prevalence among all participants. Prevalence of body dissatisfaction was very high among boy and girl university students. Moreover, body dissatisfaction among boys was a little higher than girls. Body dissatisfaction among boys was distributed equally between desired to weight-gain (47.1\%) and weight-loss (43.5\%) whereas body dissatisfaction among girls was mostly desired to weight-loss (62.3\%). Generally, girls wanted ectomorph shape. The specific area to be concerned was waist, thigh, legs, and hip, which focused on hip and butt. Boys tend to want mesomorph shape and related to muscular upper body, shoulders, arms, and chest. Boys were equally divided between desired to weight-gain and weight-loss. Boys also focused on increasing muscle mass and girls focused on decreasing fat mass (Norton \& Olds 1996). 
TABLE 1: Characteristics of a subject ( $n=276$; 138 boys and 138 girls).

Variables
Age
$<20$ years
$\geq 20$ years
Mean \pm SD (years)
BMI
Underweight
Normal
Obese
Mean $\pm S D$ (kg/m ${ }^{2}$ )
Body dissatisfaction
Satisfied
Desired to weight-loss
Desired to weight-gain
Perceived stress
Unperceived stress
Perceived stress
Mean $\pm S D$ (PSS score)

Prevalence of perceived stress was surprisingly also high among boy and girl university students. This may be due to multidimensional factors experienced by university students (Nonis et al. 1998). Cohen \& Janicki-Deverts (2012) stated that girls tended to have higher stress than boys. This study found that perceived stress was higher among boys $(71.7 \%)$ than girls $(66.7 \%)$. It could be related to the perception of the importance of academic control among university students (Nonis et al. 1998).

Obesity prevalence among university students was 23 boys (16.7\%) and 15 girls (10.9\%). This finding supported the latest data from the Basic Health Research in Indonesia (Riskesdas 2013), showing obesity prevalence among men was $19.7 \%$ in 2013 . This number may increase every year. Urbanization with an unhealthy diet and sedentary lifestyle were implicated as the main, although not the only, cause of obesity (Ko \& Chan 2007).

\subsection{Body dissatisfaction and obesity}

Prevalence of body dissatisfaction was higher among obese ones (95.7\% boys; $100 \%$ girls) than those non-obese ones ( $89.6 \%$ boys; $87 \%$ girls). It showed that none of the obese girls dissatisfied by their body. Buxton (2008) stated that women who were overweight or obese tend to have higher body dissatisfaction than healthy women. A malaise of body shape and size is endemic in women and called as a normative discontent. Mass media may influence the ideal concept of beauty, health, and wellness. Since childhood, 
boys and girls have exposure to body stereotype that has a tremendous psychosocial influence. Dolls, movie characters, models, dancers, and superheroes portrayed a specific ideal body shape. For example, Barbie is a reference model for girls (Norton \& Olds 1996). Pruis \& Janowsky (2010) found that young girls and older women had similar body dissatisfaction, but more adolescent girls had a higher drive for thinness and greater influences from society to their body image. Both of young girls and older women also had similar acceptable body size and body shape concern.

TABLE 2: The relationship between body dissatisfaction and perceived stress to obesity

\begin{tabular}{|c|c|c|c|c|c|c|c|}
\hline \multicolumn{2}{|c|}{ Variables } & \multicolumn{4}{|c|}{ Obesity $^{3}$} & \multirow{3}{*}{$\chi^{2}$} & \multirow[t]{3}{*}{ p } \\
\hline & & \multicolumn{2}{|c|}{ Non-Obese } & \multicolumn{2}{|c|}{ Obese } & & \\
\hline & & $\mathbf{n}$ & $\%$ & $\mathbf{n}$ & $\%$ & & \\
\hline \multirow{9}{*}{$\begin{array}{l}\text { Body } \\
\text { dissatisfaction }{ }^{1}\end{array}$} & Boy & & & & & & \\
\hline & Satisfied & 12 & 10.4 & 1 & 4.3 & 0.832 & $0.695^{a}$ \\
\hline & Dissatisfied & 103 & 89.6 & 22 & 95.7 & & \\
\hline & Subtotal & 115 & 100 & 23 & 100 & & \\
\hline & Girl & & & & & & \\
\hline & Satisfied & 16 & 13 & 0 & 0 & 2.207 & $0.216^{a}$ \\
\hline & Dissatisfied & 107 & 87 & 15 & 100 & & \\
\hline & Subtotal & 123 & 100 & 15 & 100 & & \\
\hline & Total & 238 & 100 & 38 & 100 & 2.907 & 0.148 \\
\hline \multirow[t]{9}{*}{ Perceived stress ${ }^{2}$} & Boy & & & & & & \\
\hline & $\begin{array}{l}\text { Unperceived } \\
\text { stress }\end{array}$ & 32 & 27.8 & 7 & 30.4 & 0.064 & 0.8 \\
\hline & Perceived stress & 83 & 72.2 & 16 & 69.6 & & \\
\hline & Subtotal & 115 & 100 & 23 & 100 & & \\
\hline & Girl & & & & & & \\
\hline & $\begin{array}{l}\text { Unperceived } \\
\text { stress }\end{array}$ & 37 & 30.1 & 9 & 60 & 5.385 & $0.020^{*}$ \\
\hline & Perceived stress & 86 & 69.9 & 6 & 40 & & \\
\hline & Subtotal & 123 & 100 & 15 & 100 & & \\
\hline & Total & 238 & 100 & 38 & 100 & 2.644 & 0.104 \\
\hline
\end{tabular}

${ }^{1}$ Satisfied: there was no discrepancy between current and ideal body shape, dissatisfied: there was a discrepancy between current and ideal body shape;

${ }^{2}$ Unperceived stress: PSS-score $\leq 16$, perceived stress: PSS-score $>16$;

${ }^{3}$ Non-obese: $\mathrm{BMI}<25 \mathrm{~kg} / \mathrm{m}^{2}$, obese: $\mathrm{BMI} \geq 25 \mathrm{~kg} / \mathrm{m}^{2}$;

* Significance $p<0.05$;

${ }^{a} \mathrm{p}$ Fisher's exact test cause could not meet the demand of chi-square test condition, one of the cells not more than 5 .

Even though, Table 2 showed that there was no significant association between body dissatisfaction among obese and non-obese boys and girls ( $p>0.05$ ), prevalence of body dissatisfaction was also high among those non-obese ones ( $89.6 \%$ boys; $87 \%$ girls). The 
high percentage of normal and underweight girls and boys was dissatisfied by their body. Itcould be related to the peak of body attention occurs during age of 20 s (Norton \& Olds 1996).

\subsection{Perceived stress and obesity}

Prevalence of perceived stress was higher among non-obese students $(72.2 \%$ boys; $69.9 \%$ girls) than those of obese ones (69.6\% boys; $40 \%$ girls), however significant relationship was found only among girls $\left(\chi^{2}: 5.385 ; p=0.020\right)$. This finding was contradictive with our hypothesize and previous findings which stated that there was a positive association between body weight and stress (Edmond, 2006) and stress might affect the risk for obesity through behavioral processes (Barrington et al. 2014). This study found that there was a negative relationship between perceived stress to obesity among girls significantly.

Prevalence of perceived stress was lower among obese than those non-obese ones. Perceived stress decreased by $29.9 \%$ among obese girls. Some possible explanations were that obesity commonly occurred in people having a high socioeconomic status which stress level was low. People, especially Indonesians, have an image that overweight or obesity is a symbol of prosperity (Indra et al. 2006). Kurniawati (2007) found that almost obese students had high-end socioeconomic status. Socioeconomic factors contribute to knowledge, attitude, behavior, lifestyle and eating behaviors that affect obesity. Cohen \& Janicki-Deverts (2012) indicated that the prevalence of stress increase in lower education and income levels. It was supported by evidence that socioeconomic status associated with the decreased morbidity and mortality.

Another study found that stressful event was often followed by significant decreases in caloric intake, body weight, and lymphocyte count and an increase in serum cortisol (Willis et al. 1987). There are two possible effects of stress, weight gain, and weightloss. Property al. (2013) found that healthy weight adult responded differently to the stress of adverse life events than those of overweight ones. An adult with a healthy weight reduced an average of $0.2 \mathrm{~kg}$ weight. Kivimaki (2006) also found that workers in the leanest BMI quintile, work stress indicators associated with weight-loss. Among those in the highest BMI quintile, work stress indicators were related to weight gain. These findings could explain that significant association between perceived stress and obesity among girl university students as possible. Pathologic obesity and overweight were commonly followed by different emotional responses. Some obese people may feel annoyed with their weight then withdraw from society and promise to control their 
weight. Other obese people may escape to uncontrolled eating and overeating when felt annoyed (Misnadiarly 2007).

Nevertheless, we lacked information on socioeconomic data, which was important as a factor that contributed to obesity. The nature of cross-sectional study also limited our ability to discuss causality. Small sample size to represent university students in Yogyakarta which was called as "student city" and simple sampling method limited the statistical power.

\section{Conclusions}

Our results showed that there was a negative relationship between perceived stress and obesity among girl university students in Yogyakarta. Prevalence of perceived stress was higher among non-obese students than those of fat ones. On the other hand, the incidence of body dissatisfaction was higher among obese boys and girls than those non-obese ones although there was no significant relationship between body dissatisfaction and obesity. This study highlighted the high number of body dissatisfaction and perceived stress among university students in Yogyakarta Province. Further studies were important for additional understanding factors associated with body dissatisfaction, perceived stress, and obesity.

\section{Acknowledgments}

Authors give special thanks to students in Universitas Gadjah Mada and Universitas Teknologi Yogyakarta for participation in this study. Thanks to all members of this study for conducting the data collection.

\section{References}

[1] Barasi, M. E. 2009. At a glance ilmu gizi. Translated by Halim, H. Jakarta: Erlangga.

[2] Barrington, W. E., Beresford, S. A. A., McGregor, B. A. \& White, E. 2014. Perceived stress and eating behaviors by gender, obesity-status, and stress vulnerability: findings from the Vitamins and Lifestyle (VITAL) study. Journal Academy of Nutrition and Dietetics, 114(11):1791-1799. https://www.ncbi.nlm.nih.gov/pmc/ (accessed Oct 18, 2016)

[3] Buxton, B. K. 2008. Body image and women: How does obesity fit into the picture? Bariatric Nursing and Surgical Patient Care, 3,4, 2008. http://search.proquest.com (accessed Oct 6, 2014) 
[4] Cohen, S. \& Janicki-Deverts, D. 2012. Who's stressed? Distributions of psychological stress in the United Stated in probability samples from 1983, 2006 and 2009. Journal of Applied Social Psychology, 41,6:1320-1334. http://tandfonline.com (accessed Mar 30, 2015)

[5] Cohen, S. \& Williamson, G. 1988. Perceived stress in a probability sample of the United States. In: Spacapam, S. \& Oskamp, S. (Eds.). The social psychology of health: Claremont Symposium on applied social psychology. Newburry Park, CA: Sage. http://www.psy.cmu.edu (accessed Sep 16, 2014)

[6] Cohen, S., Kamarck, T. \& Mermelstein, R. 1983. A global measure of perceived stress. Journal of Health and Social Behaviors, 24:385-396. http://www.psy.cmu.edu (accessed Sep 16, 2014)

[7] Edmond, J. C. 2006. The relationship of weight, body image, self-efficacy, and stress to health-promoting behaviors: A study of college-educated African American women. Ph.D. diss., The Catholic University of America.

[8] Indra, M. R., Ratnawati, R., Lyrawati, D. \& Muliartha, K. 2006. Fight obesity from cells to the community. Malang: Laboratorium IImu Faal FK UNIBRAW.

[9] Kementerian Kesehatan Republik Indonesia. 2013. Riset Kesehatan Dasar: RISKESDAS 2013. Balai Penelitian dan Pengembangan Kesehatan Kementerian Kesehatan. http://depkes.go.id (accessed May 23, 2014)

[10] Kivimaki, M., et al. 2006. Work stress, weight gain, and weight loss: evidence for bidirectional effects of job strain on body mass index in the Whitehall II study. International Journal of Obesity, 30:982-987. http://www.nature.com/ijo (accessed Oct 25, 2016)

[11] Ko, G. T. C. \& Chan, J. C. N. 2007. The burden of obesity-lessons learned from Hong Kong Chinese. Journal Compilation the International Association for The Study of Obesity, 9,1:35-40. http://search.ebscohost.com/ (accessed Oct 21, 2016)

[12] Kurniawati, D. 2007. Hubungan tolerance stress dengan kecenderungan binge eating disorder dan obesitas pada siswa SMA Muhammadiyah 1 Yogyakarta. Undergraduate thesis., Universitas Gadjah Mada.

[13] Lahey, B. B. 1980. Maladaptive behavior: An introduction to abnormal psychology. United States of America: Scott Foresman Professional Books.

[14] Misnadiarly. 2007. Obesitas sebagai faktor risiko beberapa penyakit, ed. 1. Jakarta: Pustaka Obor Populer.

[15] Nonis, A. S., Hudson, G. I., Logan, L. B. \& Ford, C. W. 1998. Influence of perceived control over time on college students' stress and stress-related outcomes. Research in Higher Education, 39,5:587-605. http://www.ncbi.mlm.nih.gov (accessed Apr 2, 2015) 
[16] Norton, K. \& Olds, T. 1996. Anthropometric: A textbook of body measurement for sports and health courses. Adelaide: UNSW Press.

[17] Proper, K. I., Picavet, H. S. J., Bogers, R. P., Verschuren, W. M. M. \& Bemelmans, W. J. E. 2013. The associations between adverse life events and body weight change: results of a prospective cohort study. BMC Public Health, 13:957. http://www.biomedcentral. com (accessed Oct 25, 2016)

[18] Pruis, T. A. \& Janowsky, J. S. 2010. Assessment of body image in younger and older women. The Journal of General Psychology, 137,3:225-238. http://sciencedirect.com (accessed Oct 21, 2016)

[19] Richardson, A. S., Arsenault, J. E., Cates, S. C. \& Muth, M. K. 2015. Perceived stress, unhealthy eating behaviors, and severe obesity in low-income women. Nutrition Journal, 14:122. https://nutritionj.biomedcentral.com (accessed Oct 18, 2016)

[20] Smith, E., Sweeting, H. \& Wright, C. 2013. 'Do I care?' Young adults' recalled experiences of early adolescent overweight and obesity: a qualitative study. International Journal of Obesity, 37:303-308. http://online.sagepub.com (accessed Sep 27, 2016)

[21] Soegih, R. \& Wiramihardja, K. K. 2009. Obesitas: permasalahan dan terapi praktis. Jakarta: Sagung Seto.

[22] Thompson, M. A. \& Gray, J. J. 1995. Development and validation o a new body-image assessment scale. Journal of Personality Assessment, 64(2):258-269. http://search. ebscohost.com/ (accessed Oct 22, 2016)

[23] Willis, L., Thomas, P., Garry, P. J. \& Goodwin, J. S. 1987. A prospective study of response to stressful life events in initially healthy elders. Journal of Gerontology, 42(6):627-630. http://geronj.oxfordjournals.org/ (accessed Oct 25, 2016) 